\title{
Cash in women's hands: experience from case studies in two unconditional cash transfer pilots in India
}

\author{
Dipjyoti Konwar ${ }^{1}$ \\ ${ }^{I}$ (Ph.D Scholar, Department of Human Development \&Childhood Studies, Lady Irwin College, University of \\ Delhi, India)
}

\begin{abstract}
Women of BPL households from urban settlements in Delhi slums and from rural villages of Indore district, M.P were structurally interviewed and their opinion and feelings were recorded in light of their experience of using cash transfer money for a whole year. The main findings of the interactions were any small amount of cash in women's hand creates sense of empowerment and security within and outside their families. The intervention encounters various dynamics of occurrence which indicates a positive outcome of the experiments. Cash has huge potential to bring in desired changes particularly for women issues that have been aspired for century long.
\end{abstract}

The views expressed are those of the author and do not necessarily reflect official views of the mentioned organizations in the paper.

Keywords - Cash Transfer, women empowerment, gender equalities, decision making, food security.

\section{INTRODUCTION}

Cash can empower poor individuals and households to make their own decisions for improving their lives. Cash transfers can support girls' education and promote better access and utilization of healthcare and other basic social services etc. Gender has been a major factor in cash transfer design for the past 10-15 years, as exemplified by the payment of Conditional Cash Transfers in Latin America to women with young children. By addressing gender imbalances in access to Education and putting cash directly in the hands of women, cash transfers can increase their bargaining power within the home and improve intra-household allocation of resources for human development. Cash transfers provided to women can also lessen the risk of households resorting to negative coping mechanisms. In Mexico, the Progresa/Oportunidades programme, in giving cash only to women, increased their decision-making role in household expenditure, financial security, self-esteem and social status. A gender audit of Brazil's Bolsa Família found that women's domestic status increased because the income they received was regular, while the wages of other household members was uncertain. The impact of Bolsa Família on women's labour market participation is also very strong with the participation rate of beneficiary women 16 percent greater than for women in similar non-participating households. In Malawi, the Social Cash Transfer Scheme has reduced the likelihood of female and childheaded households resorting to 'risky behaviour' such as transactional sex, in order to survive (Arnold.et.al, 2011).

\section{METHODOLOGY}

This paper has been prepared based on author's experience working in "Delhi Cash transfer Pilot Study" in slum and resettlement colonies of west Delhi and in rural villages in Indore district of Madhya Pradesh under "Madhyapradesh Unconditional cash transfer study". Both studies are implemented by Self Employed Women's Association, Bharat (SEWA Bharat) sponsored by UNDP India and UNICEF India respectively. In the Delhi study of 450 BPL households, where target group were 100 self selected women households, case studies have been done randomly among 20 households of target group in three stages i.e., baseline at starting of the cash transfer(CT), midline after 6 months of CT and end line after 12 months/end of the study. Another set of case studies were done in Madhya Pradesh study throughout the year. For both studies, separate checklist has been prepared to administer for personal interview. This particular paper is based end line case studies of Delhi i.e., with women who had 1 year of utilization of cash transfer, and also in MP women who had 1 year experience of cash transfer. By the mid of 2012, Delhi study final results had come out. However, MP study final results have not come out yet.

\section{KEY FINDINGS}

In narrative with their experience of utilization of Cash Transfer, most of the women beneficiaries opined that Cash transfers into women's possession increases empowerment of women. For some, it is matter of 
food security, for another, it is matter of income security, freedom of choice. For one particular woman, just having a bank account in her name is a sense of empowerment and getting cash into that account added to her self esteem.

Food Security- Ashaben, a 47yrs old home based worker, class $10^{\text {th }}$ pass, born in rural north Delhi is a Nepali origin woman married to a Punjabi man named Gurnam singh, 50 yrs, from Vishnu garden. For this inter-caste marriage they were not accepted by her in laws family and therefore had to live in rented house though her husband had paternal joint house at tilak nagar. He is a cycle- Ricksaw mechanic who works at roadside. Whenever he gets works; depending on that income varies, sometimes even don't bring a rupee home and sometime manages to earn Rs 200/- a day. They had 2 daughters, 1 died, other separated from husband, living with them with her daughter. She came back from her in laws house after $1^{\text {st }}$ child was born. Their Daughter is also $10^{\text {th }}$ pass out, makes paper bags for nearby factories. She is also a home based worker, for 1000 bags she gets 100-150 rupees. For Asha ben, choosing Cash Transfer was an obvious choice without any objection from the family members. She was not getting her entitlements from ration shop of PDS fully so why not she opt for CT. Overall, she herself and her family are having food security for 20 days as a result of CT, rest 10 days they could manage from their earnings. Ashaben looks after everything, from withdrawing money to shopping groceries and food items to other activities. She said, has a sense of security now. Ashaben is very happy and does not want ration anymore from 'sarkari ration ka dukan'. She exclaim "I would love to take Cash transfer forever as with money I am sure of securing our family food needs" she says.

Increasing confidence- Kalabai is 48years of age, a scheduled caste woman holding 1.75 bighas of land in village gogakhedi, Indore district, Madhya Pradesh. Her husband Chunnilal Solanki is 58years, small farmer and also an agricultural worker. Her elder son Sohan is 24years old, 10th fail, wage labourer in Indore. Her younger son Anil 22 years of age, studying B.Com second year at Indore college. Their daughter Arti is 20years old, 10th pass. She stays at home, does tailoring and stitching, makes swaalwar kameez and blouses for customers within the village. Their daughter in law Kiran 20 years old is also a wage labourer. According to their views, due to the cash transfer activity and interaction with SEWA workers, women of their village are becoming self confident and aware of many new things, as a result their participation has increased. They feel like expressing their opinions in a better way in front of other members in the family. She thinks women should be economically independent and also believes that women's participation in decision making within the family should be improved and increased.

Decision making- Seema Bhil is a 20 years woman and a mother of 2 children. She belongs to Scheduled Tribe and an agricultural worker. Her husband Shyam Lal is 22years old. Father-in-law Babulal is 65years old, an agricultural worker and farmer. Her first mother-in-law Dhanibai is 55years old also works in agricultural fields. Her second mother-in-law Santhabai is 50 years old works as sevika in village anganwadi. Santhabai gets Rs. 1000 per month. Seema believes that women should be economically independent; only then they will be able to participate actively in decision-making process. Generally her father-in-law and her husband take the decisions regarding financial matters and farming. They discuss with women before taking decisions regarding children's education. She takes food related decisions. Regarding social and religious matters they consult with women. Women can take decisions regarding food, children's education and other household work. In her view, the money by the government should be given to each because every person has her / his own requirements. Seema very confidently announced that as far as her money was concerned, she herself took all the decisions as to what she should spend on. Then, she added that she had spent her money for different things at different points of time. At the time of delivery, she had withdrawn Rs. 2300. It went entirely for the medical expenses for herself and the child. After that, she bought two sarees for herself (Rs. 400) two jeans for her son (Rs. 600), shoes for her son (Rs.40) etc. This adds a sense of 'feel good' factor for her.

Financial security- Rajraniben is a widow, 62 yrsof old who lives at raghubir nagar in a house owned by her brother but she does not give any rent. She has 3 children, 2 daughters married and 1 unmarried son living with her. Her husband died 14 years back, since then she has been struggling a lot with her life. Her Son is 10th pass. Sometimes back, he worked as a Tiffin supplier at some canteen and then worked as a salesman for few days. There is no fixed work that her son does. She is concern of her own economic independence and financial security since long before. Her son does not have any interference in household or monetary matters till now. She has the full control of the money that she is earning or whatever she is getting from the Cash Transfer. She is getting old age pension and also got Cash Transfer for food. She gets rupees 3000/- in three months as old age pension and rupees 1000/- per month from cash transfer for food. Thus, her monthly income may be summed up as 2000/- rupees. In these days inflated market, this money is not enough but still it is better something than nothing. According to her, these two are the biggest confidence in her life now. She somewhat feels secure with these two cash transfers. 
Emergency need and increased activity- Rambha bai 65 years of age is a housewife. She is a keer caste woman from malibadodiya, Indore district. Her husband Hariram 75 years of age is a retired farmer who is keeping unwell. Ramdev 27years old son is a farmer. Her daughter in law Sabita is 22 years old. Kishan 18 years is her daughter's son whom they adopted. Kavita 16 years is wife of kishan. Sabita's son Piyush 6 years old, studies class one in private school in Borsi. Ayush 4years old goes to anganwadi. Siya 3years old, goes to anganwadi. They use cash transfer money to meet their daily requirements - food items from the grocery shop or doctor's fees and medicines. Rambha bai said, "Sometimes I buy fruits and vegetables when a vendor comes to village. Men at my home donot take away our cash transfer money (she laughs). I didnot go out to work, so I didnot have any money with me, though my family looks after me in every way. But, still to have some money of my own is good; so that in any emergency I can take it out and buy something for myself. It is because of this cash transfer money many parents have started to send their children to private schools. Equally importantly, the poor people in the village got much help with this money. There was some discussion in the village about collecting contributions and building the temple roof, with the cash transfer money. Women have started to save money by joining the savings group. SEWA is doing a very good thing by encouraging savings, and coming regularly and enquiring about us. Ever since they started coming, the anganwadi teacher is working properly".

Along with case studies, the statistical analysis of the Delhi study examined the pattern of decisionmaking in transfer and control households. The analyses are based on results from the question on who usually makes decisions with respect to amount saved, investment in assets, regular household expenditure on food and household expenditure on children's education. A Fishers exact test was performed for each decision area to determine whether decision-making patterns were significantly different for the transfer group compared to the control group during the endlineTable-1 gives the results. It was found that statistically, transfer and control groups differ significantly in their pattern of decision-making1. The majority of respondents in the transfer group indicate they themselves make decisions in the areas considered. Compared with the control group, respondents in the transfer group are significantly more likely to take decisions on amount saved, investment in assets, regular household expenditure on food and household expenditure on children's education.

Cash transfers can promote self-esteem, status and empowerment amongst vulnerable people more generally, enabling them to be active members of their households and communities, rather than perceived as 'Burdens'. In particular, there is evidence that cash transfers can address age-based social exclusion. A Lesotho woman pensioner describes the introduction of the social pension as follows: "Before, we were treated as if we were dead. Now, people respect me."

On the other hand, for control groups, the majority of respondents indicated that their spouses usually take decisions. Relative to the transfer group, respondents' spouses are significantly more likely to take decisions on amount saved, investment in assets, regular household expenditure on food and household expenditure on children's education.

Table 1- Decision-making patterns in transfer and control groups (percentage)

\begin{tabular}{|l|c|c|c|c|c|}
\hline & & Self & Spouse & Jointly/others & Fisher's exact \\
\hline \multirow{3}{*}{ Saving } & $\mathrm{T}$ & 50 & 31.91 & 18.09 & \multirow{2}{*}{$0.02 * *$} \\
\cline { 2 - 5 } & $\mathrm{C}$ & 37.65 & 44.44 & 17.9 & \\
\hline \multirow{2}{*}{\begin{tabular}{l} 
Investment in assets \\
\cline { 2 - 5 }
\end{tabular}} & $\mathrm{T}$ & 48.94 & 31.91 & 19.15 & \multirow{2}{*}{$0.02 * *$} \\
\cline { 2 - 5 } $\begin{array}{l}\text { Regular expenditure on } \\
\text { food }\end{array}$ & $\mathrm{C}$ & 36.73 & 45.06 & 18.21 & \\
\cline { 2 - 5 } $\begin{array}{l}\text { Expenditure on children's } \\
\text { education }\end{array}$ & $\mathrm{T}$ & 56.38 & 29.79 & 13.83 & $0.06 * * *$ \\
\cline { 2 - 5 } & $\mathrm{C}$ & 48.46 & 39.51 & 11.73 & \\
\cline { 2 - 5 } & $\mathrm{C}$ & 38.87 & 32.98 & 19.15 & $0.01 * *$ \\
\hline
\end{tabular}

It would appear that women in transfer households assume a greater role in household decision-making compared with women in control households. Results from the Impact Perception Study provide additional information about the effect of cash transfers on household decision-making. Women respondents in the transfer households were asked whether they thought the cash transfer enabled them to have a greater "say" in decision-

\footnotetext{
${ }^{1}$ A Fisher's exact test reveals that decision-making patterns were significantly different at $\alpha=0.05$. This applies to all decision-making areas except decisions on regular household expenditure on food, where differences are significant at $\alpha=0.1$
} 
making on expenditure within the household. Table- 2 shows that $27 \%$ of women thought that the cash transfer enabled them to have more influence in decisions on household expenditure.

Table 2- Change in decision-making due to cash (percentage)

\begin{tabular}{|l|c|}
\hline & $\%$ \\
\hline Yes & 27.16 \\
\hline No difference & 71.60 \\
\hline Don't know & 1.23 \\
\hline Total & 100 \\
\hline
\end{tabular}

According to the results, we can deduce that cash transfers into women's bank accounts increases empowerment of women. However, since the cash transfer was made into the woman's bank account, we cannot be certain whether this is the effect of the cash transfer, the bank account or the control of the cash.

\section{CONCLUSION}

In sum, cash transfer programmes have the potential to deliver a wide range of benefits not only reducing extreme poverty, but also providing effective support for broader human development objectives, including better nutrition, health and education outputs and outcomes. Policymakers could work out universal welfare programmes designed especially for women which would deliver minimum but regular cash assistance for women. The extent to which programmes deliver these different impacts will depend critically on the availability of complementary services, the local context, and the specifics of programme design, including the transfer value. Therefore, upfront research need to be done rigorously at different levels varied from grass root to policy level.

\section{Acknowledgements}

The author would like to thank SEWA Bharat, Government of Delhi and UNDP India, UNICEF India. The author expresses her gratitude of having being part of these studies in Delhi and Madhya Pradesh. She would also like to clear that the views expressed are those of the author and do not necessarily reflect official views of the mentioned organizations in the paper.

\section{REFERENCES}

[1]. Arnold. Catherine, Conway. Tim, Greenslade. Matthew, DFID Cash Transfers-Evidence Paper policy Division (2011)

[2]. Holmes, R and Jones, N., 2010, Rethinking social protection from a gender lens. ODI Working Paper No. 320.

[3]. Ellis et al., 2008. We are all poor here: economic difference, social divisiveness, and targeting cash transfers in sub-Saharan Africa. Social Protection for the Poorest in Africa: Learning from Experience, Entebbe, Uganda.

[4]. World Bank, 2008. For protection and promotion: the design and implementation of effective safety nets. Washington DC.

[5]. Suarez et al., 2006, cited in DAC Povnet, 2009.

[6]. Veras et al., 2007, cited in DAC Povnet 2009.

[7]. Schubert, B. and Huijbregts, M., 2006. The Malawi Social Cash Transfer Pilot Scheme: preliminary lessons learnt. Paper presented at the conference Social protection initiatives for children, women and families: an analysis of recent experiences. UNICEF, New York, October 30-31 2006.

[8]. “An experimental pilot study on cash transfer in Delhi”- Final report, SEWA Bharat, 2012.

[9]. G. Standing, Cash Transfers: A Review of the Issues in India, UNICEF India Social Policy Working Paper Series No. 1 (Delhi, SEWA Bharat and UNICEF, Jan. 2012) 